And so the conclusion is drawn: " The material world is mind." Immediately after reading this, I was called by the cathedral bells to mattins, and we sang: " $O$ all ye works of the Lord, bless ye the Lord."

There is no longer any incompatibility of spirit and matter. A spiritual body is no contradiction in terms. The one fundamental difficulty hindering belief in the resurrection of the flesh is gone. That is all. The result is negative. But it clears the ground for affirmation. Resurrection is the victory of man over death in the fulness of his manhood. It is more than immortality of the soul; how much more, who knows? I know no more than I did thirty years ago how the dead are raised, or with what body they will come; but I am not on that account fool enough-I use St. Paul's rough word-to deny, or even to doubt. On grounds which seem to me sufficient, I can say without stammering that I believe in the resurrection of this flesh. T. A. LACEY.

\title{
CHURCH LIFE AS PICTURED IN CRABBE
}

\section{I}

IT has often been remarked of late that George Crabbe, after long years of neglect, is at last coming into his own. It is well if this is true. For Crabbe offers to our own and succeeding ages a distinct presentment of the manners and morals of his times. His homely pages abound in vivid pictures attractive to all who find " the proper study of mankind " an engrossing interest; and they teem in allusions to, and descriptions of, the social and religious life of the eighteenth century.

John Newton says somewhere in his Cardiphonia that the wisest students of history will be careful to trace in the history of all the ages the controlling and guiding hand of God. Such readers will discover in Crabbe much food for thought. They will find in his pages that perennial interest which the eighteenth century, midway between the semi-chivalrous Stuart period and the modern industrial world, always seems able to evoke; but also they will find much that has the deeper interest of suggesting forcibly the Divine overruling of the Church's life.

Few contemporary writers give us truer glimpses of Church life in this somewhat melancholy period than Crabbe; and that for several reasons.

In the first place, Crabbe's knowledge of English life covers wide ground. He thoroughly and intimately knew the poor, 
the tradesmen and farmers, and his fellow-clergy; whilst his early domestic chaplaincy to the Duke of Rutland gave him considerable insight into the ways of the great.

Secondly, though Crabbe is often quoted as an inefficient or negligent priest, he had no small portion of a priest's heart. We see that in his intense sympathy with the poor, and in his interest in theological questions.

Then, too, Crabbe's extraordinary powers of observation and his retentive memory make him a really effective witness to contemporary ways, whether in Church or society. In his pictures details stand out with an almost photographic minuteness which impresses and almost startles the reader.

This impression of exact detail gives us extraordinary confidence in the fidelity of the poet's descriptions; and when we have made due allowance for a somewhat strong pessimistic note, we shall suspect him of very little, if any, exaggeration. In this respect he differs from Cowper. Cowper's impatience with the Church life of his day led him to a satire which gained pungency, but lost some of its effectiveness, by its bitterness. Crabbe neither is reformer enough, nor feels keenly enough, to be led into this defect, but is content to describe things faithfully as they are.

II

Here we are considering Crabbe's description of Church life, not of the social life, of his time.

The poet deals very little with movements, but much with persons; herein he shows the rural mind. Indeed, it is the concreteness of his sketches which makes them so extraordinarily vivid. Thus it is from Crabbe's descriptions of individual parish priests rather than of religious movements that we learn something of the Church tone of his day. His poetry contains quite a gallery of ecclesiastical portraits. Whilst these seem to represent somewhat conventional types, they are also probably sketches from the life; and, indeed, ideas are conventional just because they mirror actual commonplace life. The familiar types are all there, enshrined for all time in the vivid pages: the lordly rector, the starving curate, the Methodistic Evangelical, the hunting and card-playing priest, the eager seeker for preferment. In Burials Crabbe introduces an aged sexton, and uses his garrulousness in order to introduce a description of the five rectors under whom the old man had served: the majestic Adler, who died in the pulpit; Peele, the inveterate jester, even in rebuke; Grandspear, the bountiful; the " Author- 
Rector," possibly meant as a description of Crabbe himself; and the young and fervid "Simeonite" from Cambridge.*

No one who reads the long poem entitled The Parish Register, of which Burials is a portion, will be surprised at Crabbe being described as the owner of a priestly heart. In this poem a parish priest, according to his wont at the end of each year, reviews the events recorded in his parochial registers-the baptisms, weddings, funerals; and dwells in sympathy, and often in sorrow, upon the tale of vice or happiness or suffering which the entries recall to his memory. None but a priest could well have written such a poem, with its underlying note of pastoral care and yearning for the welfare of his flock.

The reader will notice that Crabbe takes it for granted that the parish priest is intimately conversant with the joys, sorrows, and sins of all his parishioners. The eighteenth-century parson seems at least to have known his parishioners. It is true that he was not expected to practise house-to-house visiting, like his successor of to-day. But his population was smaller; and he had other methods of knowing his flock individually (he did not, for instance, despise a seat in the village inn of an evening), and seems to have used well such opportunities as outdoor sports and festivities gave him. As a matter of fact, it may be held rather uncertain how far pastoral visiting in the eighteenth century would have been altogether welcomed by parishioners. The father of the Wesleys, when Rector of Epworth, found his people unfriendly, if not actually hostile to him. They are said to have set fire more than once to his house and stacks. Fletcher of Madeley encountered bitter opposition in his pastoral efforts. Doubtless the personal collection of tithe in kind did not aid friendly relations between priest and people. The old well-known folk-song of the parson coming to the farmer to choose his tithe-pig from the sty, and, in his greed to capture the best of the litter, slipping headlong in the sty's filth, portrays an undignified and none too popular conception of the rural parson. But however much or little influence the eighteenth-century priest possessed amongst his parishioners, it is probable (and the stagnation of country life helped in this) that he knew them better than the parson of to-day, when enormous rectories and the possession of motor-cars have helped to emphasize the social distinction between shepherd and flock.

Certain is it, at any rate, that Crabbe's own very intimate understanding of the poor, and of their ways and thoughts, could be acquired only by one who had observed and thought deeply and continually about the daily lives of his flock.

\footnotetext{
* This poem was published in 1807 , and thus takes us into the early years of the nineteenth century; but what is true of the later years of the eighteenth century will fairly well describe the early years of the nineteenth.
} 
III

Here, then, we have an artist conscientious, observant, sympathetic. What is the picture of Church life which he draws for us?

Well, we find in his pages exactly the same phenomenon as in all contemporary literature: an appalling degradation of popular manners and morals, especially in the lowest and highest classes; and, at the same time, more than glimpses of an undercurrent of genuine and deep piety, strong enough to forbid our stamping the age as wholly irreligious.

On the whole, the English clergy appear, in Crabbe's pages, as a decent-living, unambitious, and distinctly somnolent class, with very little spirituality, but not altogether without regard or respect for their pastoral office. The average parish priest was doubtless a better-living man than most of his parishioners, though sometimes over-addicted to the bottle or to sport. He gave no lead in combating the vices of the day, and stood out in no marked way as superior to his flock in the higher aspirations and practices. On the whole, he stood for a conventional and unenthusiastic decency, and was contented with that-a position which was far from satisfying those of his flock who had been really stirred by some moving of the Spirit. Canon Ainger suggests that the portrait which Crabbe drew in the Tales of the Hall of an incumbent is obviously meant for the author himself as his dissenting parishioners saw him:

\footnotetext{
"A moral teacher !" some, contemptuous, cried;

He smiled, but nothing of the fact denied,

Nor, save by his fair life, to charge so strong replied.

Still, though he bade them not on aught rely

That was their own, but all their worth deny,

They called his pure advice his cold morality.
}

Morality, apart from a dogmatic basis, is singularly uninspiring for most men. Uncertainty as to the great trutbs of revealed religion (and eighteenth-century Englishmen were very dubious as to any certain revelation) naturally resulted in timidity in God's messenger, and in the sounding of an uncertain trumpet. Crabbe, in the Borough, describes the desire for peace which filled the minds of many incumbents who, in the face of " Methodist" teaching, preferred, as far as possible, to let sleeping dogs lie:

\footnotetext{
His constant care was, no man to offend;

No haughty virtues stirr'd his peaceful mind,

Nor urged the priest to leave the flock behind;

He was his Master's soldier, but not one

To lead an army of His martyrs on:

Fear was his ruling passion.
} 
This timidity and lack of spiritual fervour, partly due to the intellectual position of the times, was much increased by the great poverty of the lesser clergy. Macaulay has pointed out that the clergy of this period might be roughly divided into two classes - the great and wealthy, who moved at ease amongst the gentry and nobility; and, on the other hand, the inferior clergy, who were more at home amongst the servants in large houses, and whose children frequently went into domestic service or to farm labour.

When a man's bread and butter, and that of his family, depends largely upon his popularity, it is hardly possible for him to teach definite doctrines, regardless of their acceptability to his hearers, with courage and independence. Crabbe, in the poem quoted above, draws a painful picture of the poverty of a curate, scholarly, pious, but always in debt and want. The existing system of patronage, if that could be called system when preferment depended almost wholly upon wire-pulling, increased this evil; and we have in Crabbe, as elsewhere, pitiable glimpses of the servility of applicants for benefices, or of domestic chaplains who were glad to rank among the hired servants of the nobility.

Worse than such timidity and lack of independence was the scandal of negligent or sensual priests. In The Village the dying pauper longs in vain for spiritual ministrations; his parish priest is bent only upon sport:

\footnotetext{
Fain would he ask the parish-priest to prove

His title certain to the joys above:

For this he sends the murmuring nurse, who calls

The holy stranger to these dismal walls:

And doth not he, the pious man, appear,

$\mathrm{He}$, "passing rich with forty pounds a year"?

Ah ! no; a shepherd of a different stock,

And far unlike him, feeds this little flock:

A jovial youth, who thinks his Sunday's task

As much as God or man can fairly ask;

The rest he gives to loves and labours light,

To fields the morning, and to feasts the night;

None better skill'd the noisy pack to guide,

To urge their chase, to cheer them or to chide;

A sportsman keen, he shoots through half the day,

And, skill'd at whist, devotes the night to play:

Then, while such honours bloom around his head,

Shall he sit sadly by the sick man's bed,

To raise the hope he feels not, or with zeal

To combat fears that e'en the pious feel ?
}

When at last the pauper dies, the lazy chaplain even fails to put in an appearance at the funeral:

Now to the church behold the mourners come, Sedately torpid and devoutly dumb;

The village children now their games suspend,

To see the bier that bears their ancient friend;

IV. 23 
And like a monarch ruled their little court. The pliant bow he formed, the flying ball, The bat, the wicket, were his labours all; Him now they follow to his grave, and stand Silent and sad, and gazing, hand in hand; While bending low, their eager eyes explore The mingled relics of the parish poor:

The bell tolls late, the moping owl flies round, Fear marks the flight and magnifies the sound; The busy priest, detain'd by weightier care, Defers his duty till the day of prayer:

And, waiting long, the crowd retire distress'd,

To think a poor man's bones should lie unbless'd.

The truth is that the average Englishman of the eighteenth century (witness Mr. Edwards's oft-quoted remark to Dr. Johnson) conceived a " living" not as a cure of souls so much as a sinecure, a quiet haven of peace, little troubled by duties of any kind except on Sundays:

\footnotetext{
"What is a Church ?"-Let Truth and Reason speak, They would reply, "The faithful, pure and meek;

From Christian folds, the one selected race,

Of all professions, and in every place."

"What is a Church ?"- " A flock," our vicar cries,

"Whom bishops govern and whom priests advise;

Wherein are various states and due degrees,

The bench for honour, and the stall for ease;

That ease be mine, which, after all his cares,

The pious, peaceful prebendary shares."
}

It was from such a state of things as this that "Methodism," gradually leading to Dissent, naturally had its origin. The Methodist claimed that timidity and sloth were unbecoming in a messenger of the Gospel, the delivery of which called for all the courage and fire a man possessed; and he gradually relinquished the hope of finding these in the Church:

\footnotetext{
"Show me the churchman who will rise and pray

Through half the night, though lab'ring all the day,

Always abounding - show me him, I say:"-

Thus cries the preacher, and he adds, "Their sheep

Satan devours at leisure as they sleep.

Not so with us; we drive him from the fold,

For ever barking and for ever bold:

While they securely slumber, all his schemes

Take full effect-the devil never dreams." *
}

The Church of Crabbe's days-as, indeed, the Church of most days-was deeply conservative, and the average parson resented change. His attitude is, no doubt, accurately shown in such lines as these-though the general meaning of the passage is somewhat obscure:

* Crabbe must surely have had in his mind Bishop Latimer's pungent criticism of the non-preaching clergy of his day: "One . . . is the most diligent prelate or preacher in all England. And will ye know who it is? I will tell you: it is the devil. . . . He is never out of his diocese: he is never from his cure; ye shall never find him unoccupied . . . ye shall never find him idle, I warrant you.' 


\footnotetext{
For sects he cared not; "They are not of us,

Nor need we, brethren, their concerns discuss;

But 'tis the change, the schism at home I feel:

Ills few perceive, and none have skill to heal;

Not at the altar our young brethren read

(Facing their flock) the decalogue and creed;

But at their duty, in their desks they stand,

With naked surplice, lacking hood and band:

Churches are now of holy song bereft,

And half our ancient customs chang'd or left;

Few sprigs of ivy are at Christmas seen,

Nor crimson berry tips the holly's green;

Mistaken choirs refuse the solemn strain

Of ancient Sternhold, which from ours amain

Comes flying forth from aile to aile about,

Sweet links of harmony and long drawn out.
}

Crabbe shared this common antipathy of Churchmen to such novelty as the " enthusiasm " of the Methodists, preferring the somnolence of the old régime to the uncertain extravagances into which the new preaching sometimes led its hearers. He writes harshly, even violently, of Wesley's preaching, and hardly more sympathetically of the young Simeonite vicar of the Burials :

\footnotetext{
Him in his youth a clamorous sect assail'd, Advised and censured, flatter'd-and prevailed. Then did he much his sober hearers vex, Confound the simple, and the sad perplex; To a new style his reverence rashly took; Loud grew his voice, to threat'ning swell'd his look; Above, below, on either side he gazed, Amazing all, and most himself amazed:

No more he read his preachments pure and plain, But launch'd outright, and rose and sank again: At times he smiled in scorn, at times he wept, And such sad coil with words of vengeance kept, That our best sleepers started as they slept.
}

Methodist and Simeonite were forerunners of those gallant leaders of the Catholic revival who would have been equally abhorrent to Crabbe and to those who felt with him. It was characteristic of the eighteenth century to fear any spiritual movement.

\section{IV}

We see, then, in Crabbe, something of the resentment of those who see in spiritual matters a new power gathering force which they can neither understand nor control.

Side by side with this restlessness (it is really the restlessness of a giant trying to awake from sleep) we find in the Church evidences of a quiet devotional life which held its own amidst much surrounding unbelief and immorality. Some of Crabbe's happiest lines describe the pious poor. In a charming picture -all the more charming because of the appalling sketch of rural vice immediately following - he describes the cottage home of 
the industrious and thrifty peasant, its furniture, its pictures, and its books:

On shelf of deal beside the cuckoo-clock,

Of cottage-reading rests the chosen stock;

Learning we lack, not books, but have a kind

For all our wants, a meal for every mind:

The tale for wonder and the joke for whim,

The half-sung sermon and half-groan'd hymn.

No need of classing; each within its place,

The feeling finger in the dark can trace; . .

There pious works for Sunday's use are found;

Companions for that Bible newly bound;

That Bible, bought by sixpence weekly sav'd,

Has choicest prints by famous hands engraved;

Has choicest notes by many a famous head,

Such as to doubt have rustic readers led.

Here is a simple portrait of one who might well have dwelt in the home described above:

A noble Peasant, Isaac Ashford, died.

Noble he was, contemning all things mean,

His truth unquestion'd, and his soul serene:

Of no man's presence Isaac felt afraid;

At no man's question Isaac look'd dismay'd:

Shame knew him not, he dreaded no disgrace;

Truth, simple truth, was written in his face.

The rector tells his feeling of loss when Isaac died:

I feel his absence in the hour of prayer,

And view his seat and sigh for Isaac there:

I see no more those white locks thinly spread

Round the bald polish of that honour'd head;

No more that awful glance on playful wight,

Compelled to kneel and tremble at the sight,

To fold his fingers, all in dread the while,

Till Mister Ashford soften'd to a smile;

No more that meek and suppliant look in prayer,

Nor the pure faith (to give it force) are there:-

But he is bless'd, and I lament no more

A wise good man contented to be poor.

Could words better than these depict the Evangelical lover of Scripture and good works ?

Upon the sure and written Word she trusts,

And by the Law Divine her life adjusts;

She blames not her who other creed prefers,

And all she asks is charity for hers.

Her great example is her gracious Lord,

Her hope his promise, and her guide his Word;

Her quiet alms are known to God alone,

Her left hand knows not what her right has done.

One of Crabbe's most charming poems, untouched by his prevalent pessimism, is entitled Silford Hall, or The Happy Day, in which he describes the happy day spent by an imaginative village lad who has been sent on an errand to a great country mansion, and is allowed to wander through its rooms, accompanied by the housekeeper. The lad, full of wonder, is especially moved by the chapel: 


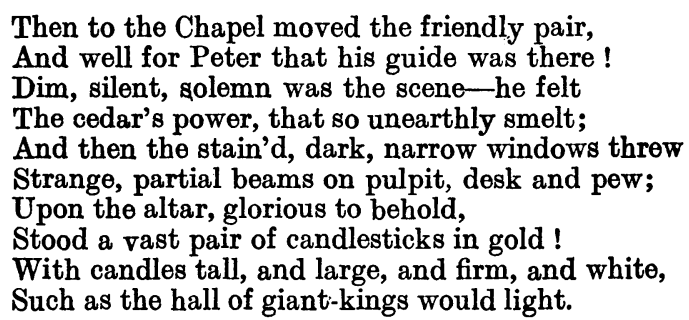

We note with interest the massive altar-lights; but it is something of a surprise to find the boy bowing reverently to sacred paintings in the picture-gallery:

The Scripture Pieces caused a serious awe,

And he with reverence looked on all he saw;

His pious wonder he express'd aloud,

And at the Saviour Form devoutly bow'd.

We shall hardly expect in Crabbe's pages to find much mention of the Blessed Sacrament. The Holy Eucharist played little part in the lives of Churchpeople in those days, though excellent manuals existed for the use of the devout; and lack of it left their religion drab and cheerless. Three or four times a year was the usual number of celebrations in the middle of the century in the ordinary parish church. In his Poor of the Borough, however, Crabbe tells of one church at least (Dr. Wickham Legg has told us of others) where the Sacrament was administered oftener, and the sexton-

Once in a month the sacramental bread

On cloth with wine upon the table spread.

The truth is that, whilst certain manuals maintained the high Eucharistic teaching of Laud and Andrewes and Ken (we have it continued in the Wesleys' hymns and writings), the English Church as a whole had little conception at this time of the Sacrament as a mystery or as a channel of divine grace.

There we may well leave our subject. The tale is told. For a conception of religion which scoffs at fervent preaching, and has no faith in sacramental grace, can have little or no power to sway the hearts of men, or to change their sinful characters. At its best such a religion can but serve to keep alive for a while a sense of Christian decency, and be a quiet hearth, so to speak, from which, when the Holy Spirit fans the embers, may spring - as actually happened soon after Crabbe laid down his pen-a living flame of preaching zeal and of faith in those unseen realities which Sacraments unfailingly deliver.

$$
\text { Rev. G. LaCey MaY. }
$$

